\title{
HUBUNGAN ANTARA SIKAP TERHADAP EVALUASI GURU BK DENGAN KETERLAKSANAAN PROGAM BIMBINGAN DAN KONSELING
}

\author{
Dina Rahmawati Hapsyah*); Nina Fitriyani; Riska Handayani; Theodora Nurmalia; \\ Afan Abdul Jabbar; Deni Purwanto; Aip Badrujaman \\ Universitas Negeri Jakarta \\ *)email: dinarahmawati_bk18s2@mahasiswa.unj.ac.id
}

\footnotetext{
Paper Accepted: 21 Juni 2019 Paper Reviewed: 23-29 Juni 2019 Paper Edited: 01-18 Juli 2019 Paper Approved: 28 Juli 2019
}

\begin{abstract}
Attitudes towards program evaluation need to be owned by guidance and counseling teachers in implementing programs so that the services provided are of higher quality. This study aims to look at the relationship between the teacher's counseling and counseling attitudes towards program evaluation and the implementation of guidance and counseling programs. In this study, the subjects of the study population were guidance and counseling teachers at Serang District (Banten) State Middle School, amounting to 30 people. The instrument used is the teacher's attitudes of guidance and counseling towards the evaluation of basic services used to obtain information about the teacher's attitudes of guidance and counseling on evaluating basic services and instruments for the implementation of guidance and counseling programs used to describe the evaluations carried out by teachers guidance and counseling . The results showed that $50 \%$ of the guidance and counseling teachers had good knowledge of the guidance and counseling teacher evaluation, as many as 63 guidance and counseling teachers had good opinions on the evaluation of guidance and counseling. The results of the study on the implementation of the guidance and counseling program evaluation showed that $47 \%$ of guidance and counseling teachers carried out an evaluation of counseling and guidance program planning, $53 \%$ of guidance and counseling teachers carried out process evaluation, $59 \%$ of guidance and counseling teachers carried out evaluation results, while evaluation of counseling programs was $53 \%$.
\end{abstract}

Keywords: Attitudes toward Guidance and Counseling Teacher Evaluation, Implementation of Guidance and Counseling Programs.

\section{PENDAHULUAN}

Sebagai bentuk tanggung jawab profesi sebagai guru bimbingan dan konseling tidak dapat dilepaskan dari segala upaya yang dicurahkan dalam melaksanakan suatu program yang direncanakan. Tanggung jawab terhadap profesi sangat melekat dalam diri guru bimbingan dan konseling. Program bimbingan dan konseling disusun oleh guru bimbingan dan konseling mulai dari tahap perencanaan hingga evaluasi program. Program bimbingan dan konseling disusun berdasarkan kebutuhan/masalah, kekhasan sekolah atau lingkungan sekitar yang menuntut peserta didik dapat mengembangkan potensi yang dimiliki sesuai harapan diri, keluarga, dan masyarakat. Agar program bimbingan dan konseling yang direncanakan dapat tercapai, diperlukan dukungan dan komitmen antar personil bimbingan dan konseling yang terdiri dari kepala sekolah, guru mata pelajaran, wali kelas, petugas administrasi, peserta didik, orang tua peserta didik, serta lingkungan. Bukan hanya guru bimbingan dan konseling yang 
melaksanakan dan melakukan evaluasi program, tetapi stakeholder sekolah juga turutmendukung, memonitor dan memberi penilaian atau evaluasi terhadap pelaksanaan layanan bimbingan dan konseling sesuai program yang direncanakan.(Hastuti, 2013)menyebutkan bahwa kerja sama antara guru bimbingan dan konseling serta pemangku jabatan dapat dilakukan, koordinasi atau komunikasi dengan pihak lain demi keberhasilan layanan, peran kepala sekolah dalam monitoring kegiatan bimbingan dan konseling dan penyelenggaraan layanan dasar, memberikan kesempatan untuk memberikan layanan di kelas, serta menyusun laporan hasil layanan pada akhir semester atau akhir tahun pelajaran.

Kegiatan evaluasi program perlu dilakukan dalam mencapai efektifitas dan efisiensi layanan yang diberikan oleh guru bimbingan dan konseling.Sutoyo dan Supriyanto (2015) dalam (Supriyanto A. , 2016) menjelaskan kegiatan perencanaan, pengorganisasian, pelaksanaan, serta evaluasi menjadi suatu syarat dalam menilai profesionalitas guru bimbingan dan konseling di sekolah.Guru bimbingan dan konseling hendaknya mampu melaksanakan evaluasi terhadap program layanan dan terbuka pada perubahan dalam meningkatkan kualitas layanan. Dengan demikian, guru bimbingan dan konseling dapat melaksanakan evaluasi dengan cara mengamatidan mempertimbangkan program layanan dengan tujuan yang ingin dicapai, seperti mengetahui kelebihan dan kekurangan program, tindakan dalam mempertahankan atau mengembangkan program yang sudah baik, serta mengambil keputusan apabila program memiliki keterbatasan di lapangan. Sesuai Petunjuk Pelaksanaan Bimbingan dan Konseling di Sekolah dalam (Hastuti, 2013), kegiatan evaluasi dapat dilakukan oleh guru bimbingan dan konseling dengan mengamati kesesuaian antara rencana program dan pelaksanaan, keterlaksanaan program, hambatan yang dijumpai, respon berbagai pihak di sekolah, dampak layanan terhadap kegiatan belajar, hasil belajar peserta didik dan pencapaian tugas perkembangan, serta keberhasilan peserta didik sesudah tamat sekolah.(Hastuti, 2013)menguraikan tentang ciri - ciri kegiatan evaluasi yang bersifat formal dan informal. Evaluasi yang bersifat formal dilaksanakan sesuai desain ilmiah, prosedur yang jelas dan sistematis. Sedangkan evaluasi informal dilaksanakan tanpa mengikuti desain ilmiah tetapi melibatkan kegiatan mental dari guru bimbingan dan konseling dalam melakukan tugasnya. Evaluasi informal dapat berlangsung secara spontan yang melibatkan pikiran dan perasaan, mencari umpan balik pada hasil kerjanya, melihat persepsi dari orang lain.

Shertzer dan Stone dalam (Hastuti, 2013) menentukan kriteria dalam evaluasi program yang dapat bersifat internal (program memerlukan analisis) dan eksternal (keberadaan suatu objek). Beberapa kriteria internal dalam evaluasi program yaitu guru bimbingan dan konseling memiliki semangat yang tinggi dan kemampuan bekerja, menghindarkan dari sikap yang tahu segalanya tetapi memerlukan bantuan orang lain, menyosialisasikan program pada stakeholder sekolah, mengetahui peran dan tanggung jawab sebagai guru bimbingan dan konseling, serta menampilkan diri sebagai guru bimbingan dan konseling yang memiliki kaulifikasi akademik dalam melaksanakan memberi layanan. Pada kenyataannya, tidak banyak guru bimbingan dan konseling yang melaksanakan evaluasi program dikarenakan berbagai kendala atau masalah yang ditimbulkan dari dalam dirinya dan lingkungan sekolah. Kualifikasi akademik yang dimiliki guru bimbingan dan konseling tidak menjamin dapat melaksanakan program layanan secara efektif dan efisien. Sikap terhadap evaluasi program yang dimiliki guru bimbingan dan konseling pun masih kurang positif. Untuk itu, guru bimbingan dan konseling perlu menyikapi permasalahan tersebut dengan lebih bijak dan terbuka terhadap perbaikan atau pengembangan kepribadian dan kinerja di masa mendatang.

Untuk itu, peneliti ingin mengetahui gambaran mengenai sikap guru bimbingan dan konseling terhadap evaluasi program, keterlaksanaan program layanan, serta hubungan antara sikap guru bimbingan dan konseling terhadap evaluasi program dan keterlaksanaan program bimbingan dan konseling.

\section{SIKAP GURU BIMBINGAN DAN KONSELING}

Mardapi (Wicaksono, Muhardjito, \& Hasriati, 2016) mengungkapkan sikap adalah sesuatu hal yang mengacu pada respon dalam bentuk positif atau negatif terhadap suatu objek.Sedangkan menurut Saifudin (Hendrawan \& Sirine, 2017) sikap merupakan salah satu bentuk dari evaluasi atau reaksi pada sesuatu yang dijadikan objek, yang berpengaruh pada perasaan, tindakan, dan pemikiran seseorang yang memihak atau tidak memihak pada aspek di lingkungannya.Adanya satu kesatuan dari pikiran (kognitif) dan perasaan (afektif) pada sesuatu yang menjadi objek, sehingga menjadi 
alasan seseorang untuk menumbuhkan perilaku (konatif) terhadap objek tertentu.Jika perasaan yang dimiliki positif, maka tindakan yang di tunjukkan juga cenderung positif, begitupun sebaliknya, apabila perasaan yang dimunculkan negatif, maka tindakan yang dihasilkan juga cenderung tidak positif (Khoirunnisa, Setiyowati, \& Tjalla).

Evaluasi bimbingan dan konseling merupakan segala bentuk usaha dan tindakan atau proses dalam memberikan penilaian atas kegiatan yang berkaitan dengan pelaksanaan layanan bimbingan dan konseling, penilaian yang dilakukan atas dasar kriteria tertentu yang sesuai dengan program bimbingan dan konseling (Juntika dalam(Azizah, Ginting, \& Utami, 2017). Guru bimbingan dan konseling/konselor yang melaksanakan evaluasi program bimbingan dan konseling dapat membantu konselor dalam memberikan informasi yang terkait dengan praktik sehingga dapat meningkatkan pelayanan dalam konseling (Astramovich, Coker, \& Hoskins, 2007).

\section{KETERLAKSANAAN PROGRAM BIMBINGAN DAN KONSELING}

Guru bimbingan dan konseling perlu memiliki suatu kriteria mengenai pelaksanaan program yang telah direncanakan. Kriteria tersebut digunakan sebagai dasar dalam menilai atau mengevaluasi pelaksanaan program dan patokan dalam melihat keberhasilan suatu program dengan tujuan yang dicapai. Shertzer Stone(Hastuti, 2013) dalam bukunya Fundamental of Guidance dalam menjelaskan kriteria yang relevan bagi guru bimbingan dan konseling dalam menilai keberhasilan program, meliputi keberhasilan peserta didik dalam melanjutkan pendidikan, timbul perasaan puas dalam memegang tugas sebagai guru bimbingan dan konseling, peserta didik memiliki rencana bagi masa depan, mengungkapkan permasalahan seputar perkembangan peserta didik, berpengaruh positif bagi hasil belajar, peserta didik terlibat aktif dalam kegiatan belajar, berkurangnya peserta didik yang memiliki kasus, serta peserta didik dapat merasakan layanan yang memadai.

Selain itu, guru bimbingan dan konseling diharapkan memiliki prosedur yang dapat menjelaskan keterampilan praktis dalam melaksanakan program. Seperti yang disebutkan oleh Shertzer Stone(Hastuti, 2013), guru bimbingan dan konseling dapat merumuskan langkah kerja dalam melaksanakan program sebagai berikut:
1. Memiliki kesepakatan atau komitmen antara seluruh personil bimbingan dan konseling dalam mengadakan perubahan terhadap program yang memiliki kelemahan

2. Menentukan prioritas terhadap program yang akan dilaksanakan selanjutnya, sesuai dengan hasil evaluasi program

3. Menganalisis hambatan dalam melaksanakan program agar diadakan perubahan

4. Menyadari kenyataan yang ada dengan mempertimbangkan tujuan yang dicapai

5. Mendapatkan dukungan dari seluruh personil bimbingan dan konseling/stakeholder sekolah

Sementara itu, program bimbingan dan konseling dapat dijadikan petunjuk bagi guru bimbingan dan konseling dalam melaksanakan layanan secara efisien dan efektif(Sari, Giyono, \& Mayasari, 2013). Menurut Sukardi(Aqib, 2012), program bimbingan dan konseling diartikan sebagai sebuah rencana yang menyeluruh mengenai berbagai pelaksanaan kegiatan layanan bimbingan dan konseling pada periode tertentu, meliputi program tahunan, semesteran, bulanan, mingguan".

Menurut Sutoyo dan Supiyono dalam (Supriyanto, 2016) berpendapat bahwa "counselor need to have leadership ability, create a collaboration atmosphere between stakeholders, and technology information mastered" sehingga beberapa syarat yang diperlukandalam menilai profesionalisme guru bimbingan dan konseling/konselor adalah apabila guru bimbingan dan konseling/konselor mampu melakukan perencanaan, perancangan,pelaksanaan, serta evaluasi program bimbingan dan konseling.

Pelaksanaan program bimbingan dan konseling tidak lepas dari hubungan kerjasama antara guru bimbingan dan konseling dengan stakeholder sekolah. Hal ini telah diatur dalam Permendikbud nomor 111 tahun 2014 yang menyatakan bahwa kolaborasi dapat dilakukan oleh gur bimbingan dan konseling/konselor dengan stakeholder sekolah, seperti kepala sekolah, guru mata pelajaran, wali kelas, komite sekolah, orang tua peserta didik, dan lembaga yang berkaitan dengan program atau materi layanan bimbingan dan konseling. Dalam hal ini, guru bimbingan dan konseling/konselor berperan sebagai pihak yang memiliki keterampilan dalam menyelenggarakan layanan bimbingan dan konseling. 
Komponen layanan bimbingan dan konseling meliputi layanan dasar (proses pemberian bantuan pada seluruh peserta didik melalui kegiatan klasikal atau kelompok yang bertujuan untuk mengembangkan kemampuan penyesuaian diri yang efektif), layanan responsif (pemberian bantuan kepada peserta didik yang dilakukan segera, agar peserta didik tidak mengalami hambatan dalam proses pencapaian tugas perkembangan), perencanaan individual(bantuan yang diberikan pada peserta didikk yang bertujuan agar peserta didik mampu merencanakan dan melakukan kegiatan secara sistematis, berkaitan dengan perencanaan masa depan berdasarkan pada pemahaman diri), serta dukungan sistem (komponen layanan dan kegiatan manajemen, tata kerja, infrastruktur, dan pengembangan kemampuan profesional secara berkelanjutan, dan memberikan bantuan pada peserta didik dalam memberikan fasilitas serta mendukung efektivitas layanan bimbingan dan konseling.

\section{METODOLOGI}

Penelitian ini menggunakan pendekatan kuantitatif yang bersifat korelasional. Menurut Sugiyono (2012) metode penelitian korelasi merupakan pengukur hubungan dua variabel yang dinyatakan dalam bentuk hubungan atau fungsi. Untuk menentukan bentuk hubungan diperlukan pemisahan yang tegas antara variabel bebas $(\mathrm{x})$ yaitu sikap guru bimbingan dan konseling terhadap evaluasi layanan dasar dengan variabel terikat (y) yaitu keterlaksanaan evaluasi program bimbingan dan konseling. Kedua variabel biasanya bersifat kausal atau mempunyai hubungan sebab akibat yaitu saling berpengaruh.

Dalam penelitian ini, subjek populasi penelitian yaitu guru bimbingan dan konseling pada SMP Negeri Se-Kabupaten Serang (Banten). Adapun sampel penelitian sebanyak 30 orang. Penelitian ini dilakukan dengan menyebarkan instrumen dan pengisian instrumen dilakukan secara langsung (door to door) oleh guru bimbingan dan konseling di Kabupaten Serang, agar keabsahan data yang diperoleh dengan tepat dan sesuai dengan kebutuhan penelitian. Instrumen yang digunakan dalam penelitian ini berjumlah dua instrumen, yaitu: instrumen sikap guru bimbingan dan konseling terhadap evaluasi layanan dasar dan instrumen pelaksanaan evaluasi program bimbingan dan konseling. Instrumen sikap guru bimbingan dan konseling terhadap evaluasi layanan dasar dugunakan untuk mendapatkan informasi mengenai sikap guru bimbingan dan konseling terhadap evaluasi layanan dasar dan instrumen pelaksanaan evaluasi program bimbingan dan konseling digunakan untuk mengetahui gambaran mengenai keterlaksanan evaluasi yang dilakukan oleh guru bimbingan dan konseling.

Skala pada instrumen sikap guru bimbingan dan konseling terhadap evaluasi layanan dasar menggunakan model skala Likert. Sedangkan instrumen pelaksanaan evaluasi program bimbingan dan konseling menggunakan model skala Guttman. Analisis data menggunakan rumus teknik perhitungan korelasi product moment.

\section{HASIL}

Berdasarkan dari hasil analisis instrumen mengenai sikap terhadap keterlaksanaan evaluasi program bimbingan dan konseling di SMPN Kabupaten Serang (X). Dari hasil analisisi per-aspek dan per-indikator dapat dijelaskan sebagai berikut:

Dari 30 guru bimbingan dan konseling, sebanyak $40 \%$ atau 12 guru bimbingan dan konseling SMP Se-Kabupaten Serang memiliki sikap pada aspek kognitif yang baik dan sebanyak $60 \%$ atau 18 guru bimbingan dan konseling memiliki aspek kognitif yang buruk terhadap evaluasi bimbingan dan konseling.Adapun di dalamnya memuat indikator pengetahuan dan pendapat. Dari hasil analisis indikator pengetahuan sebanyak $50 \%$ atau 15 guru bimbingan dan konseling memiliki pengetahuan yang baik terhadap evaluasi bimbingan dan konseling dan 50\% atau 15 guru bimbingan dan konselong memiliki pengetahuan yang buruk terhadap evaluasi bimbingan dan konseling. Sedangkan indikator pendapat menunjukkan $63 \%$ atau 19 guru bimbingan dan konsleing memiliki pendapat yang baik terhadap evaluasi guru bimbingan dan konsleing dan 37\% atau 11 guru bimbingan dan konseling memiliki pendapat yang buruk terhadap evaluasi bimbingan dan konseling, berikut ini ditampilkan diagram presentase: 


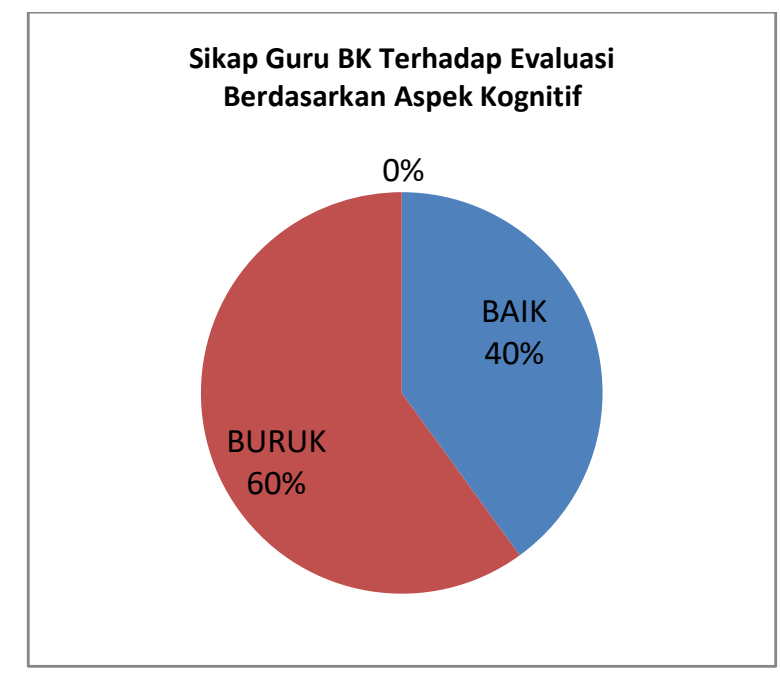

Dari 30 guru bimbingan dan konseling, sebanyak $47 \%$ atau 14 guru bimbingan dan konseling SMP Se-Kabupaten Serang memiliki sikap pada aspek afeksi yang baik dan $53 \%$ atau 16 guru bimbingan dan konseling memiliki aspek afeksi yang buruk terhadap evaluasi bimbingan dan konseling. Adapun aspek tersebut terdapat dua indikator yaitu indikator perasaan dan indikator penilaian. Dari hasil analisis per-indikator dapat dijelaskan bahwa dalam indikator perasaan terdapat $50 \%$ atau 15 orang guru bimbingan dan konseling memiliki perasaan yang baik terhadap evaluasi bimbingan dan konseling dan 50\% atau 15 guru bimbingan dan konseling memiliki perasaan yang buruk terhadap evaluasi bimbingan dan konseling. Sedangkan pada indikator penilaian memiliki penilaian terhadap evaluasi sebanyak $37 \%$ atau 11 guru bimbingan dan konseling dan 50\% atau 15 guru bimbingan dan konseling memiliki penilaian yang buruk terhadap evaluasi bimbingan dan konseling, berikut ditampilkan diagram presentase:

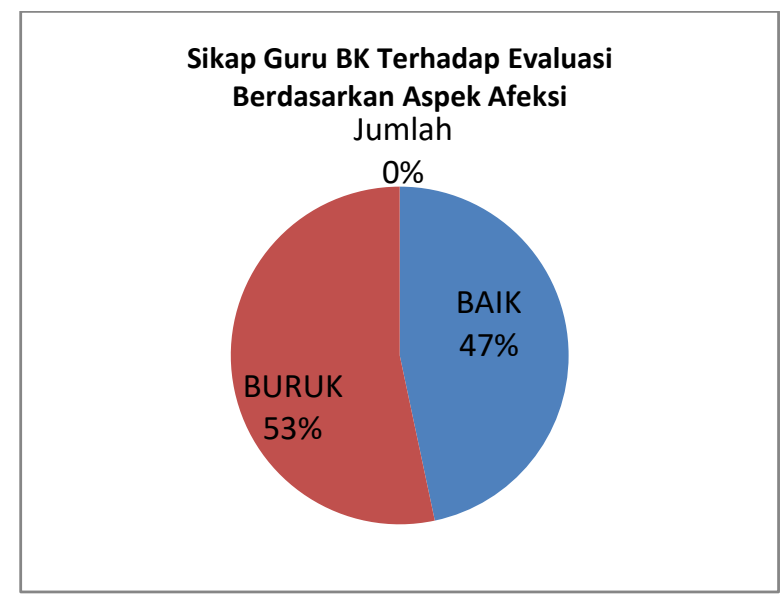

Akan tetapi, hasil tersebut berbeda ditunjukkan oleh guru bimbingan dan konseling SMP Se-Kabupaten Serang yaitu pada aspek konatif karena dalam aspek konatif sebanyak $60 \%$ atau 18 guru bimbingan dan konseling memiliki sikap pada aspek konatif yang baik dan $40 \%$ atau 12 guru bimbingan dan konselingmemiliki aspek konatif yang buruk terhadap evaluasi bimbingan dan konseling. Pada aspek konatif diatas terdapat dua indikator yaitu indikator kecenderungan berperilaku dan merespon. Dari hasil analisis indikator 
kecenderungan berperilaku sebanyak 57\% atau 17 guru bimbingan dan konseling memiliki kecenderungan berperilaku baik terhadap evaluasi bimbingan dan konsleing dan $43 \%$ atau 13 guru bimbingan dan konseling memiliki kecenderungan berperilaku buruk terhadap evaluasi bimbingan dan konseling. Sedangkan dalam indikator kecenderungan merespon sebanyak $43 \%$ atau 13 guru bimbingan dan konseling memiliki kecenderungan merespon yang buruk terhadap evaluasi bimbingan dan konseling.

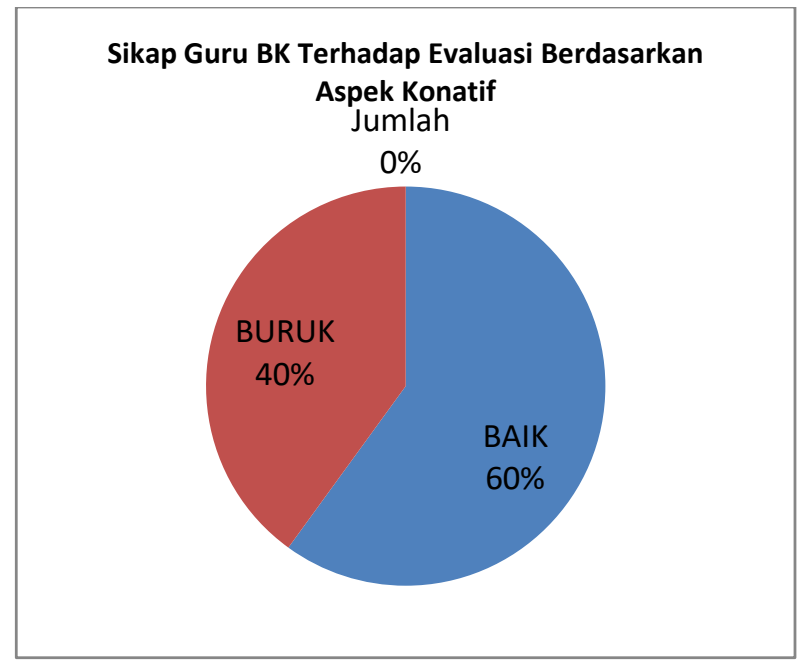

Berdasarkan hasil analisis pada keterlaksanaan evaluasi program bimbingan dan konseling menunjukkan bahwa 53\% atau 16 guru bimbingan dan konseling melaksanakan evaluasi pada program bimbingan dan konseling yang telah mereka laksanakan dan sebanyak
47\% atau 14 guru bimbingan dan konseling tidak melaksanakan evaluasi program bimbingan dan konseling, berikut ditampilkan diagram keterlaksanaan evaluasi program bimbingan dan konseling:

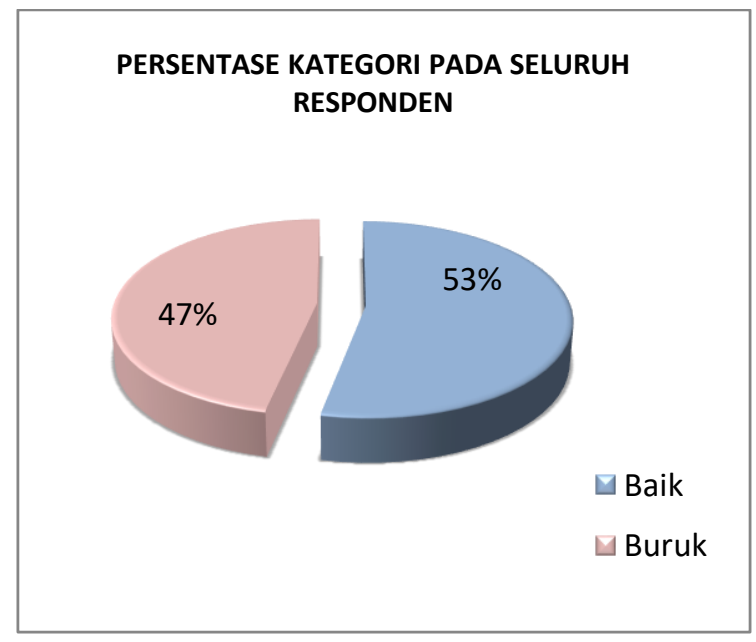

Sedangkan berdasarkan aspek-aspek keterlaksanaan evaluasi program bimbingan dan konseling sebanyak $47 \%$ guru bimbingan dan konseling melaksanakan evaluasi perencanaan program bimbingan dan konseling, sebanyak $53 \%$ guru bimbingan dan konseling melaksanakan evaluasi proses program bimbingan dan konseling, sementara sebanyak 
$59 \%$ guru bimbingan dan konseling melaksanakan evaluasi hasil program bimbingan dan konseling, sedangkan dalam evaluasi program konseling sebanyak 53\%, berikut ditampilkan diagram :

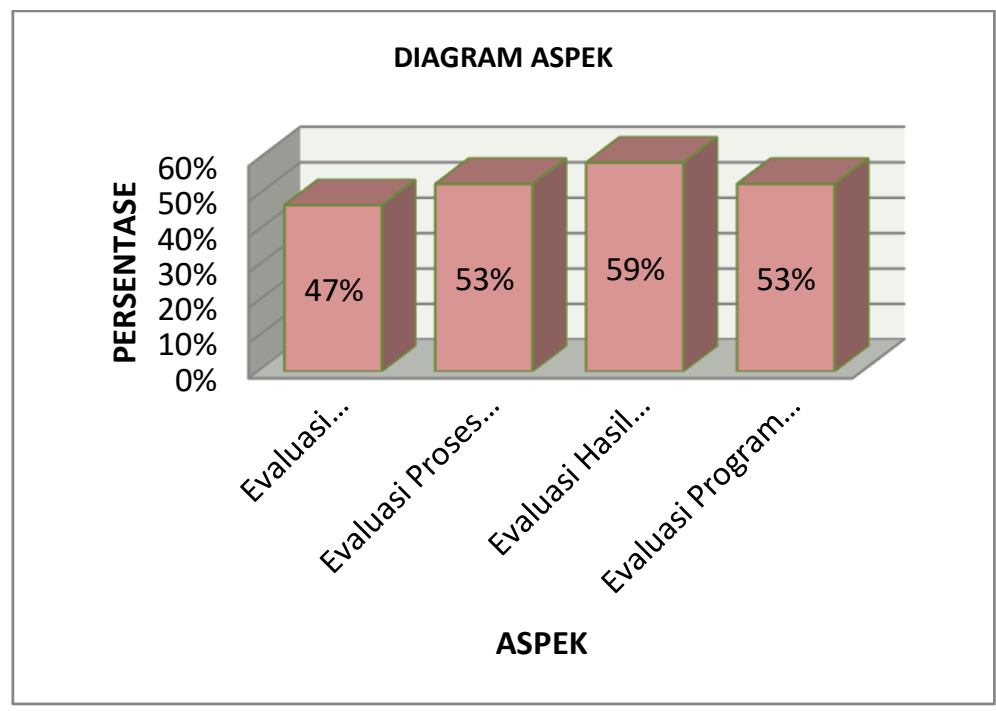

\section{PEMBAHASAN}

Hasil penelitian serupa juga dikemukakan oleh Khoirunnisa, Setiyowati, \& Tjalla(2017) dalam penelitian Sikap Guru Bimbingan Dan Konseling Terhadap Evaluasi Program Bimbingan Dan Konseling (survey pada guru bimbingan dan konseling SMP di Bekasi Timur) dari hasil penelitian tersebut menunjukkan bahwa sikap guru bimbingan dan konseling terhadap evaluasi program bimbingan dan konseling cenderung memiliki sikap mendukung dengan persentase $57 \%$ sedangkan sikap guru bimbingan dan konseling yang menolak dengan persentase $43 \%$. Kedua hasil ini dipengaruhi oleh pemahaman, opini, perasaan dan kecenderungan perilaku yang mereka miliki serta factor-faktor yang mempengaruhi terbentuknya sikap.

Sejalan dengan hasil penelitian yang dilakukan (Badrujaman, 2012) mengenai Faktor-Faktor Yang Mempengaruhi Keterlaksanaan Evaluasi Program Bimbingan Dan Konseling menunjukkan bahwa terdapat dua faktor utama yang menyebabkan guru bimbingan dan konseling tidak melakukan evaluasi program bimbingan dan konseling yaitu: 1) kurangnya keterampilan dalam melakukan evaluasi, 2) beban kerja yang tinggi. Sedangkan faktor-faktor yang mempengaruhi keterlaksanaan secara rendah adalah hasil program bimbingan dan konseling sulit diukur, kurang lengkapnya data, kurangnya anggaran dana/keuangan bimbingan dan konseling, kurang mampu menetapkan kriteria evaluasi bimbingan dan konseling yang relevan, takut kelemahannya diketahui adanya tenaga yang merangkap, ketersediaan rasio guru bimbingan dan konseling masih kurang, kurang dukungan kepala sekolah.

Sedangkan hasil penelitian yang dilakukan oleh Saputra(2015) menemukan bahwa Evaluasi Program Konseling Di SMP Kota Malang menggunakan model Discrepancy Model yaitu evaluasi program konseling di SMP Kota Malang masih jauh dari standar hal ini dikarenakan pada SMP tersebut hanya 51,1\% aspek kegiatan program konseling telak terlaksana dengan baik. Sementara pada SMP tersebut setidaknya $17,8 \%$ aspek kegiatan program konseling hanya terlaksana sebagian. Sedangkan untuk program konseling yang tidak terlaksana sama sekali di SMP tersebut yaitu $31,1 \%$.

Namun peneliti juga menemukan bahwa guru bimbingan dan konselingSMP SeKabupaten Serang memiliki sikap yang buruk terhadap evaluasi program bimbingan dan konseling. Mereka dapat melaksanakan evaluasi program bimbingan dan konseling dengan baik. Ada beberapa alasan yang ditemukan, yaitu: 1) kurangnya pemahaman mengenai tahapan evaluasi, 2) tidak melaporkan hasil evaluasi yang terstruktur, 3) pelaporan evaluasi terhadap program lebih bersifat verbal dan tidak 
diwajibkan, 4) kurangnya keterampilan teknologi, 5) tidak adanya masukan-masukan dari siswa terkait pelaksanaan program bimbingan dan konseling.

\section{PENUTUP}

Menurut Shertzer dan Stone dalam (Hastuti, 2013), adanya hambatan dalam melaksanakan evaluasi program bimbingan dan konseling masih sering terjadi dan dapat menjadi kendala bagi guru bimbingan dan konseling. Begitupula dengan pandangan Shaw dalam (Hastuti, 2013) yang mengatakan bahwa kebanyakan guru bimbingan dan konseling menganggap dirinya sebagai orang lapangan yang melaksanakan program layanan daripada melaksanakan riset atau evaluasi program.Dengan demikian, guru bimbingan dan konseling perlu memiliki kesadaran dan sikap yang positif terhadap layanan yang diberikan mulai dari perencanaan program hingga evaluasi program. Guru bimbingan dan konseling/konselor yang melaksanakan evaluasi program bimbingan dan konseling dapat membantu dirinya dan orang lain dalam memberikan informasi, terkait dengan praktik sehingga dapat meningkatkan pelayanan dalam konseling (Astramovich, Coker, \& Hoskins, 2007). Lebih lanjut, pandangan Shaw dalam (Hastuti, 2013) menegaskan bahwa ciri - ciri kepribadian yang berperan dalam pengambilan sikap evaluatif menunjukkan tidak terdapat korelasi positif pada ciri - ciri kepribadian yang memiliki minat pada profesi sebagai guru bimbingan dan konseling/konselor. Sehingga, evaluasi bimbingan dan konseling sebagaibentuk usaha dan tindakan atau proses dalam memberikan penilaian atas kegiatan yang berkaitan dengan pelaksanaan layanan bimbingan dan konseling tetap perlu dilaksanakan untuk meningkatkan kualitas layanan bimbingan dan konseling serta mendukung program sekolah.

\section{DAFTAR PUSTAKA}

Aqib, Z. (2012). Ikhtisar Bimbingan \& Konseling Di Sekolah. Bandung: Yrama Widya.

Astramovich, R., Coker, J., \& Hoskins, W. (2007). Training School In Program
Evaluation. Profesional School

Counseling.

Azizah, F., Ginting, H. F., \& Utami, R. S. (2017). Evaluasi Pelaksanaan Program Layanan Bimbingan Dan Konseling Di Sekolah. Prosiding Seminar Bimbingan Dan Konseling.I, hal. 177-188. Malang: Universitas Negeri Malang.

Badrujaman, A. (2012). Faktor-Faktor Yang Mempengaruhi Keterlaksanaan Evaluasi Program Bimbingan Dan Konseling. Perspektif Ilmu Pendidikan, 87-93.

Hendrawan, J. S., \& Sirine, H. (2017, September). Pengaruh Sikap Mandiri, Motivasi, Pengetahuan Kewirausahaan Terhadap Minat Berwirausaha. AJIE : Asian Journal of Innovation And Entrepreneurship, II(3), 291-314.

Khoirunnisa, R., Setiyowati, E., \& Tjalla, A. (t.thn.). Sikap Guru Bimbingan dan Konseling Terhadap Evaluasi Program Bimbingan dan Konseling.

Sari, E., Giyono, \& Mayasari, S. (2013). Faktor Penghambat Pelaksanaan Program Bimbingan Dan Konseling. ALIBKIN, 112.

Saputra, W. N. (2015). Evaluasi Program Konseling Di Smp Kota Malang: Discrepancy Model. Jurnal Psikologi Pendidikan \& Konseling , 180-187.

Supriyanto, A. (2016). Profesionalisme Konselor : Evaluasi Program Bimbingan Dan Konseling Komprehensif Di Sekolah. Membangun Karakter Untuk Memperkokoh Persatuan Dan Kesatuan Bngsa. Surabaya: Seminar Nasional LP3M.

Winkel, W.S. dan Sri Hastuti. 2005. Bimbingan dan Konseling di Institusi Pendidikan. Yogyakarta: Media Abadi.

Peraturan Menteri Pendidikan Dan Kebudayaan Nomor 111 Tahun 2014 Tentang Bimbingan Dan Konseling Pada Pendidikan Dasar Dan Pendidikan Menengah. (2014).

Wicaksono, T. P., Muhardjito, \& Hasriati, T. (2016). Pengembangan Penilaian Sikap Dengan Teknik Observasi, Self Assesment, dan Peer Assesment Pada Pembelajaran Tematik Kelas V SDN Arjowinangun 02 Malang. Jurnal Pendidikan : Teori, Penelitian, dan Pengembangan, I(1), 45-51. 